\title{
Shortenings: clipping, acronyms and blending as productive ways of forming religious lexis in the English language
}

\author{
M. I. Boichuk \\ Ivan Franko Lviv National University \\ Corresponding author. E-mail: marianaboichuk91@gmail.com
}

Paper received 09.02.21; Accepted for publication 20.02.21.

https://doi.org/10.31174/SEND-Ph2021-248IX73-03

\begin{abstract}
Religious lexis represents spiritual and mental values of human beings through expressing their worldviews. This study aims to determine the productive ways of forming religious lexis in the English language. Some of such ways of creating new words are clippings, acronyms and blending. The authors begin to study the general overview of the main features and characteristics of shortening processes. Special attention is paid to clipping, acronyms and blending and the productivity of these linguistic phenomena for the religious vocabulary. Based on a structural analysis of a comprehensive English dictionary a variety of the example of acronyms, blended words and clipped words have been presented and distinguished the difference between back formation and clipping. The results indicate that the religious vocabulary is not lacking these processes, but further research is needed to identify other ways of word-formation processes for the religious sphere.
\end{abstract}

Keywords: shortening, clipping, acronyms, blending.

The religious English vocabulary is enriched by different means of word formation. Some of the most productive ways to form the religious lexis are clipping, acronyms and blending. To analyze the productivity of clipping, acronyms and blending we have analyzed the lexical volume of the comprehensive English-Russian dictionary of religious terminology. The reason for active usage of clipping, acronyms and blending is that, the life tempo is increasing and we need to provide more and more information in shorter time.

The analysis of the issues of shortening is rather incomplete, so the problems of shortened new lexical units as a specific phenomenon of rationalization of speech activity attract the attention of many domestic and foreign linguists. E. Kubriakova and K. Dyuzhikova defined the boundaries between shortening and word formation, I. Stern, M. Schlauch, L. Shelyakhovska and L. Sapogova explore the basic principles of shortening modeling.

The desire of the English language to reduce word is noted by many scholars, including Charles Bally, who indicates that: "English, which strives for monosyllabism, turns the zoological garden into a zoo..., popular concerts into pops..." [3, c. 333]. By shortening we mean the process of truncating the base of a word or truncating an entire phrase, resulting in words with an incomplete, reduced base (or bases).

F. Katamba provides a somewhat related definition of shortening, but adds a phonological dimension to its definition, arguing that shortening is a term for the formation of a new word form with the same meaning as the original lexical term, by cutting the part off and reducing it to onesyllable or two-syllable parts [7, c. 180]. According to the classification of V. Borisov [4, c. 97], shortenings are divided (according to the method of implementation in speech) into graphic and lexical. The main distinction between graphic and lexical abbreviations is that graphic abbreviations are symbols that are used instead of words or phrases in written language, and lexical abbreviations are independent words in the field of oral communication. Graphic abbreviations are conventional graphic notation of words; in oral speech, these symbols are not reflected in any way, as they are read as complete words or phrases.
There are three main types of lexical shortening: clipping, acronyms and blending.

Clippings are divided into apocopes (according to I. Arnolad) [2] (cutting the end part off) doc (doctor), sis (sister), exam (examination); apheresis (cutting the initial part off) phone (telephone), plane (airplane); syncopes (removal of the central part) maths (mathematics), comms (communications), mart (market) and mixed (truncation of the initial and final part of the word) flu (influenza), fridge (refrigerator). R. Stockwell and D. Minkova [8] consider back formation as cases of shortening: edit $(<<$ editor $)$; burgle $(<<$ burglar); peddlar $(<<$ peddle), but we believe that these word-formation processes are different, because the reverse word-formation changes the class of words, and the origin of most truncated forms can be established.

Analyzing the comprehensive English-Russian dictionary of religious terminology [1] we have found out that religious lexis is shorted by clipping the final part (apocopes): arch - archbishop, apoc - 1) apocalypse 2) apocrypha, 3) apocryphal, archd. - archdeacon, bap./bapt. - baptized, Bib. - Bible, cath. - catholic, chap. - chaplain, icon. - iconography, Jes. - Jesus, meth. - methodist, myst - 1) mysteries; 2) mysticism, Nativ. - Nativity of Christ, prod. (prot.) - protestant, script. - scripture, theos. - 1) Theosophist, 2) Theosophy, 3) Theosophical, Old. Test. - Old Testament, and removal of the central part: Ecclus. - Ecclesiasticus, Supt. - superintendent, Xmas. - Christmas, Xtian. - Christian, Xtianity - Christianity.

Many examples of the graphic shortenings have been explored in the dictionary mentioned above: abp. - archbishop, Bib. - Bible, Chr - 1) Christ, 2) Christian, conf. confessor, Div. - Divinity, Fr. - Father, Go. - Gothic, Pr. priest, Ps. (Psa.) - psalm, ref. - refectory, rel. (relig.) - religion, Rev. - Reverend, St. - Saint, Supt. - superintendent, Msgr. - monsignor.

Clipping can be formed by using two word-formation methods at the same time: shortening and suffixation, for example, in children's language the words hanky, unkie are formed by shortening the nouns handkerchief and uncle, preserving only their initial parts han and uns, and adding suffixes -y, -ie, which give the words diminutive and affectionate shades. In the word baccy (tobacco) the first syllable disappears, and the addition of the suffix absorbs the final 
vowel of the full word (-o).

Another productive way of forming religious lexis is by using acronyms. An acronym is an abbreviation whose phonetic structure coincides with the phonetic structure of commonly used words. Parts of words that are part of the initial terminological words are used to form acronyms.

There are two main types of acronyms:

1) those that are pronounced literally, or they are called alphabets or letter abbreviations: IFR (International Fellowship of Reconciliation), RIP - requiescat in pace, ALC - American Lutheran Church, ASP Anglo-Saxon, BCC - British Council of Churches, B.F.B.S. - British and Foreign Bible Society;

2) those that are pronounced as if they were ordinary words written in the same letters, i.e. they merge in pronunciation, for example: TEC [tek] - The Episcopal Church, RELC - Reformation Evangelical Lutheran Church.

R. S. Ginzburg, S. S. Khidekel, G. Y. Knyazeva, A. A. Sankin [5, c. 190] distinguish two more types of acronyms: acronyms may be formed from the initial syllables of each word of the phrase, e.g. Interpol - inter/national pol/ice; tacsatcom - Tactical Satellite Communications: Capcom - Capsule Communicator (the person at a space flight centre who communicates with the astronauts during a space flight) and acronyms may be formed by a combination of the abbreviation of the first or the first two members of the phrase with the last member undergoing no change at all, e.g. V-day - Victory Day; H-bomb - hydrogen bomb; g-force - gravity force, etc.

In addition, there are words that are formed by the letter abbreviation of only the first element in the case of a twomembered, and the first and second elements in the case of a three-membered combination, while the final element is not abbreviated: AME Zion Church - African Methodical Episcopal Church of Zion.

A significant role in the creation of religious vocabulary is played by the process in which a new word arises from the fusion of the complete basis of one word with the shortened basis of another or from the merger of the shortened bases of two words, this process is called blending.

In linguistics there is no single definition of blending units, and therefore to denote this phenomenon, scientists use the following concepts: telescoping, telescoped words, blend, blendings, contamination, portmanteau words.

Blendings are formed not by a mechanical reduction of the original bases, but by a purposeful, semantically-motivated reduction, the creation of a new word from two (or more) "fragments", as a rule, with a new subjective and logical meaning. The difference between blendings and compoundings is that in compounds the components are whole bases, and in blendings at least one of the components is not a whole, but a reduced form, its fragment. Unlike abbreviations, blendings, as a rule, do not have equivalents in free phrases, but are formed as a result of establishing associative connections between syntactically separated words.

In structural terms, four main models have been identified, according to which blendings have been formed in recent decades:

1) merging of a reduced form with a reduced form: dramedy (drama + comedy), memberlect (remember + recollect);

2) merging of the full form with a reduced form: video-log (video + catalogue), pocketphone (pocket + telephone), jazzercise (jazz + exercise);

3) merging of the reduced form with a full form: teleplay (television + play), mocamp (motor-car + camp);

4) merging of two bases with the element of overlapping at the junction of these bases of pronunciation, or writing: faction (fact + fiction); Singlish (Singapore English); autotel (auto + hotel).

As a rule, blendings are two-element units, but there are also three-element mergers, for example: Ameslan - the language of the deaf and dumb in the United States - American sign language.

Most abbreviations account for nouns, adjectives and verbs are rarely abbreviated, although the latter retain their temporal features: fantabulous, adj (fantastic + fabulous); to babynap, v (to kidnap a baby).

Among the layer of religious vocabulary we trace the following examples of blending:

chorepiscopal (choral+episcopal) - (in early Christianity) relating to or connected with a local bishop). Analyzing the structure of this lexical unit we relate it to the 1 model of blending;

chrismon (Christ+monogram) - the monogram and symbol of Christ's name, also known as chi-rho (1 model);

cosmogony (kosmos + gonos ("birth") - the study of the origin and development of the universe or of a particular system in the universe, such as the solar system (1 model);

chugger (charity + mugger) - a charity worker who approaches people in the street to ask for financial support for the charity, esp regular support by direct debit (1 model);

Churchianity (Church + Christianity) - loyalty to the church rather than Christianity (2 model);

demochristian (democratic + Christian) - a member or supporter of a Christian democratic party or movement (3 model);

manuscript (manus hand + scribere to write) - a written or typewritten document or paper, esp. the copy of an author's work that is submitted to a publisher or printer (1 model);

nothingarian (nothing + ending from Unitarian) - a person who has no or little political or theological affiliation; a person who does not believe in or stand for anything in particular (2 model);

orthopraxy (orthos correct + praxis deed, action) - the belief that right action is as important as religious faith (1 model);

sext (from contraction of sex (n.) + text $(v))$.- the fourth of the seven canonical hours of the divine office or the prayers prescribed for it: originally the sixth hour of the day (noon) (2 model);

televangelism (television+evangelism) - evangelism as preached on television by televangelists ( 1 model);

therianthropic (thērion wild animal + anthrōpos human being) - conceived of as being partly human and partly animal in form (4 model);

theriomorphic (thērion wild animal + morphē shape) possessing or depicted in the form of a beast (4 model);

ding $($ din + ring $)-$ an imitation or representation of the sound of a bell (2 model);

natureligion (nature + religion) (2 model);

Ziontology (Zion + Scientology) (2 model).

According to the results of the work, we have found out 
that shortenings play a leading role in the formation of religious lexical units and perform a function of "more eco- nomical" substitutes for compound words. Phrases of nominative character are especially often the object to reduction.

\section{ЛИТЕРАТУРА}

1. Азаров А. А. Большой англо-русский словарь религиозной лексики, 2004. - 808 с.

2. Арнольд И.В. Лексикология современного английского языка. - 2-е изд., 2012. - 376 с.

3. Балли Ш. Французская стилистика, 2001. - 392 с.

4. Борисов В. В. Аббревиация и акронимия Военные и научно-технические сокращения в иностранных языках, 1972. -319 c.

5. R. S. Ginzburg, S.S. Khidekel, G. Y. Knyazeva and A. A. Sankin, Лексикология английского языка: Учебник для ин-тов и фак. иностр. zз. - 2-е изд., испр. и доп., 1979. - 269 с. 6. Collins Online English Dictionary [Электронный pecypc]. Режим доступа: https://www.collinsdictionary.com/dictionary/english/

7. Katamba F. Morphology / Katamba. - London: Macmillan, 1993. - 354 p.

8. R.Stockwell, D. Minkova. English words: History and Structure, 2001. -208 p.

\section{REFERENCES}

1. Azarov A.A. Comprehensive English-Russian Dictionary of Religious Terminology, 2004. - $808 \mathrm{p}$.

2. Arnold I.V. Lexicology of Modern English. - 2nd ed., Rev., 2012. $-376 \mathrm{p}$.

3. Bally Ch. French stylistics, 2001. - 392 p.

4. Borisov V.V. Abbreviation and acronyms. Military, scientific and technical abbreviations in foreign languages, 1972. - 319 $\mathrm{p}$

5. R. S. Ginzburg, S.S. Khidekel, G. Y. Knyazeva and A. A. San- kin. Lexicology of the English language: Textbook for institutes and fac. of foreign language - 2nd ed., Rev. and add., 1979. $-269 \mathrm{p}$.

6. Collins Online English Dictionary [Электронный ресурс]. Режим доступа: https://www.collinsdictionary.com/dictionary/english/

7. Katamba F. Morphology / Katamba. - London: Macmillan, 1993. - $354 \mathrm{p}$.

8. R.Stockwell, D. Minkova. English words: History and Structure, 2001. -208 p. 